\title{
Tolerance of coriander cultivars under saline stress
}

\author{
Francisco Vanies da Silva Sá ${ }^{1 \star}$, Lauter Silva Souto ${ }^{1}$, Emanoela Pereira de Paiva ${ }^{2}$, Miguel
} Ferreira Neto $^{2}$, Rosilene Agra da Silva ${ }^{1}$, Maria Kaline do Nascimento Silva ${ }^{1}$, Evandro Franklin de Mesquita ${ }^{3}$, Fernandes Antônio de Almeida ${ }^{1}$ and Antônio Alves Neto ${ }^{1}$

\author{
${ }^{1}$ Federal University of Campina Grande, Campina Grande, Paraíba, Brazil. \\ ${ }^{2}$ Federal University of Rural of Semi-Árido, Mossoró, Rio Grande do Norte, Brazil. \\ ${ }^{3}$ State University of Paraíba (UEPB), Catolé do Rocha, Paraíba, Brazil.
}

Received 3 July, 2016; Accepted 19 September, 2016

\begin{abstract}
This study aimed to evaluate the emergence, growth and phytomass accumulation of coriander cultivars under saline stress. The experiment was carried out from August to September 2014, in a protected environment (greenhouse), at the Center of Sciences and Food Technology - CCTA of the Federal University of Campina Grande - UFCG, located in the municipality of Pombal-PB, Brazil $\left(6^{\circ} 47^{\prime} 20^{\prime \prime}\right.$ S; $37^{\circ} 48^{\prime} 01^{\prime \prime}$ W; $\left.194 \mathrm{~m}\right)$. Two coriander cultivars $\left(C_{1}-\right.$ 'Verdão SF $177^{\prime}$ and $C_{2}$ - 'Português Pacífico') were evaluated under five levels of irrigation water salinity (0.6 (control); 1.2; 1.8, 2.4 and 3.0 dS $\mathrm{m}^{-1}$ ), arranged in a $2 \times 5$ factorial scheme, in a randomized block design, with four replicates and five plants per replicate. Coriander plants were cultivated on trays of 36 cells with capacity for $0.1 \mathrm{dm}^{3}$ of substrate, until 20 days after sowing, and evaluated for emergence, growth, phytomass accumulation and tolerance to salinity. The increase in irrigation water salinity reduced emergence percentage, growth and phytomass accumulation of coriander plants. The cultivar 'Português Pacífico' is more tolerant to salinity than 'Verdão SF 177'. The cultivars 'Português Pacífico' and 'Verdão SF 177' can be irrigated with water of up to 2.6 and $1.9 \mathrm{dS} \mathrm{m}^{-1}$, respectively, in the initial growth stage.
\end{abstract}

Key words: Coriandrum sativum, salinity, emergence, initial growth.

\section{INTRODUCTION}

Coriander (Coriandrum sativum L.) is a leafy vegetable widely consumed in Brazil, especially in the Northeast region, where it is largely used in the regional cuisine; thus having great alimentary and socioeconomic importance for being cultivated during the entire year, generating jobs and income to small- and medium-sized producers (Silva et al., 2012; Sales et al., 2015). However, its cultivation in the Northeast region requires irrigation, due to the climatic conditions, such as high atmospheric demand and low rainfalls (Oliveira et al., 2010).

In the Brazilian semiarid region, there is great availability al., 2015; Araújo et al., 2016). However, depending on of waters with saline concentrations unviable for direct use in the conventional irrigation of most crops (Silva et al., 2012) the period of the year, the

*Corresponding author. E-mail: vanies_agronomia@hotmail.com.

Author(s) agree that this article remain permanently open access under the terms of the Creative Commons Attribution 
Table 1. Chemical characteristics of the components of the substrate used in coriander cultivation.

\begin{tabular}{|c|c|c|c|c|c|c|c|c|c|c|c|c|}
\hline & CE & pH & $\mathbf{P}$ & $\mathrm{K}^{+}$ & $\mathrm{Ca}^{+2}$ & $\mathrm{Mg}^{+2}$ & $\mathrm{Na}^{+}$ & $\mathrm{Al}^{3+}$ & $\mathrm{H}^{+}+\mathrm{Al}^{3+}$ & SB & $T$ & MO \\
\hline & $\mathrm{dS} \mathrm{m}^{-1}$ & $\mathrm{H}_{2} \mathrm{O}$ & $\mathrm{mg} \mathrm{dm}^{-3}$ & & ב-.-- & -...-... & -.---cr & $\mathrm{dm}^{-3}$ & 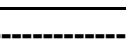 & |------- & & $\mathrm{g} \mathrm{kg}^{-3}$ \\
\hline A & 0.09 & 8.07 & 3.00 & 0.32 & 6.40 & 3.20 & 0.18 & 0.00 & 0.00 & 10.49 & 10.49 & 16.0 \\
\hline B & 1.65 & 5.75 & 86.00 & 1.67 & 11.60 & 28.50 & 17.84 & 0.00 & 11.88 & 59.61 & 71.49 & 570.0 \\
\hline
\end{tabular}

$\mathrm{SB}=$ Sum of bases; $\mathrm{EC}=$ electrical conductivity; $\mathrm{T}=$ total cation exchange capacity; $\mathrm{OM}=$ organic matter; $\mathrm{A}=$ soil; $\mathrm{B}=$ commercial substrate.

Table 2. Chemical analysis of the public-supply water used in the preparation of the solutions.

\begin{tabular}{|c|c|c|c|c|c|c|c|c|c|c|}
\hline$C E_{a}$ & $\mathrm{pH}$ & K & $\mathrm{Ca}$ & $\mathbf{M g}$ & $\mathrm{Na}$ & $\mathrm{SO}_{4}^{-2}$ & $\mathrm{CO}_{3}{ }^{-2}$ & $\mathrm{HCO}_{3}^{-}$ & $\mathrm{Cl}^{-}$ & SAR $^{1}$ \\
\hline $\mathrm{dSm}^{-1}$ & & \multicolumn{7}{|c|}{ 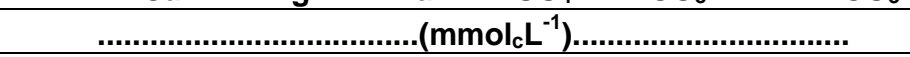 } & \multicolumn{2}{|c|}{$\left(\mathrm{mmol}_{\mathrm{c}} \mathrm{L}^{-1}\right)^{0,5}$} \\
\hline 0.3 & 7.0 & 0.3 & 0.2 & 0.6 & 1.4 & 0.2 & 0.0 & 0.8 & 1.3 & 2.21 \\
\hline
\end{tabular}

${ }^{1} \mathrm{SAR}=$ Sodium adsorption ratio.

water used for the irrigation of crops contains high levels of salts, which limit the development of the crops, especially coriander (Rebouças et al., 2013). In addition, most rural producers of vegetables perform irrigations with water collected in superficial reservoirs, which may have high concentration of dissolved salts (Oliveira et al., 2014). In these cases, the use of saline water is conditioned to the tolerance of the crops to salinity and the adequate irrigation management (Medeiros et al., 2007).

Considering that not all crops respond equally tosalinity, some produce acceptable yields at high saline levels and others are sensitive to relatively low levels (Santana et al., 2007). It can be said that the tolerance to salinity is variable among species and, even within the same species, among development stages, in each stage, the tolerance to salinity is controlled by more than one gene, highly influenced by environmental factors (Flowers and Flowers, 2005; Esteves and Suzuki, 2008; Munns and Tester, 2008; Taiz and Zeiger, 2013). These differences are due to the capacity of osmotic adaptation that some genotypes have, which allows them to absorb greater amount of water, even under conditions of high salinity (Ayers and Westcot, 1999).

Given the above, this study aimed to evaluate the emergence, growth and phytomass accumulation of coriander cultivars under saline stress.

\section{MATERIALS AND METHODS}

The experiment was carried out from August to September 2014, in a protected environment (greenhouse), at the Center of Sciences and Food Technology - CCTA of the Federal University of Campina Grande - UFCG, located in the municipality of Pombal-PB, Brazil (647'20" S; 3748'01" W; $194 \mathrm{~m}$ ).

Two coriander cultivars $\left(\mathrm{C}_{1}\right.$ - 'Verdão SF 177' and $\mathrm{C}_{2}-$ 'Português Pacífico') were evaluated under five levels of irrigation water salinity ( 0.6 (control); $1.2 ; 1.8,2.4$ and $\left.3.0 \mathrm{dS} \mathrm{m}^{-1}\right)$, arranged in a $2 \times 5$ factorial scheme, in a randomized block design, with four replicates and five plants per replicate, totaling 200 plants.
Coriander plants were cultivated on trays of 36 cells with capacity for $0.1 \mathrm{dm}^{3}$ of substrate, until 20 days after sowing (DAS). The substrate for seedlings production was composed of soil (typic $\mathrm{Tb}$ eutrophic Fluvic Neosol) (Embrapa, 2013) and commercial substrate, mixed at the proportion of $1: 1$, respectively, and its chemical characterization is shown in Table 1 (Embrapa, 2011). At sowing, five tray cells were used for each treatment, and each cell received two seeds, totaling 10 seeds per treatment. After seedlings emergence finished, thinning was performed leaving only the most vigorous plant per cell. The seeds of both cultivars were purchased in a store, with $99 \%$ of purity and $95 \%$ of germination.

Irrigations were daily performed, in order to maintain the substrate with moisture content close to the maximum retention capacity, based on the method of drainage lysimetry, and the applied water depth was added to a leaching fraction of $20 \%$. The volume applied $\left(\mathrm{V}_{\mathrm{a}}\right)$ per container was obtained by the difference between the previous volume applied $\left(\mathrm{V}_{\text {prev }}\right)$ minus the mean drainage (D), divided by the number of containers $(n)$, as indicated in Equation 1.

$V_{a}=\frac{V_{\text {prev }}-(D / n)}{1-L F}$

Irrigation waters with different levels of salinity were prepared considering the relationship between $\mathrm{EC}_{\mathrm{w}}$ and concentration of salts (10*meq $\mathrm{L}^{-1}=1 \mathrm{dS} \mathrm{m}^{-1}$ of $\mathrm{EC}_{\mathrm{w}}$ ), according to Rhoades et al. (1992), which is valid for $E C_{w}$ of 0.1 to $5.0 \mathrm{dS} \mathrm{m}^{-1}$, which comprehend the tested levels. Water from the local supply system $\left(E_{\mathrm{w}}=0.3 \mathrm{dS} \mathrm{\textrm {m } ^ { - 1 }}\right)$ was used, mixed with salts $(\mathrm{NaCl})$ as necessary (Table 2).

After preparation, the salinized waters were stored in $30-\mathrm{L}$ plastic containers, one for each studied level of $\mathrm{EC}_{\mathrm{w}}$, which were properly protected to avoid evaporation, entry of rainwater and contamination with materials that could compromise their quality. For the preparation of the waters, with the respective levels of electrical conductivity (EC), the salts were weighed according to the treatments and water was added until the desired EC level. The values were confirmed using a portable conductivity meter, adjusted to temperature of $25^{\circ} \mathrm{C}$.

During the experiment, the emergence of coriander plants was monitored by counting the number of emerged plants, that is, with cotyledons above soil surface, without discarding them, thus obtaining a cumulative value. After stabilization of emergence, emergence percentage (EP) (\%) was determined through the relationship between the number of emerged plants and the number of planted seeds. 
Crop morphological aspects were monitored through the growth analysis of the seedlings at 20 DAS, was performed with the determination of plant height $(\mathrm{PH})(\mathrm{cm})$, measured with a graduated ruler as the distance from the soil to the apex of the plant, stem diameter (SD), measured with a digital caliper, $1 \mathrm{~cm}$ high from the soil surface, and number of leaves (NL), through the count of mature leaves. After growth analysis, the plants were collected, separated into shoots and roots, and dried in a forced-air oven at $65^{\circ} \mathrm{C}$ until constant mass. Then, the material was weighed on an analytical scale for the determination of shoot dry matter (SDM) (mg) and root dry matter (RDM) (mg). Total dry matter (TDM) (mg) was then determined through the sum of SDM and RDM.

The data of total dry matter production were used to calculate the percentages partitioned between vegetative organs and the salinity tolerance index, comparing the saline treatments with the control

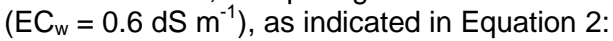

$S T I(\%)=\frac{\text { TDM production in saline treatment }}{\text { TDM production in control treatment }} \times 100$

The total dry matter production of the genotypes was used in the calculation of these indices as the main parameter for the determination of their tolerance to saline stress.

The obtained data were subjected to analysis of variance by $F$ test and, in cases of significance, regression analyses were applied for the factor levels of irrigation water salinity and Tukey test for the factor cultivars, both at 0.05 probability level, using the statistical program SISVAR $®$ (Ferreira, 2011).

\section{RESULTS AND DISCUSSION}

There was significant influence $(p<0.05)$ of the interaction of coriander cultivars vs. levels of irrigation water salinity in the studied variables (Figure 1). The increase in irrigation water salinity linearly reduced EP of coriander plants, with decreases of $18.52 \%$ for the cultivar 'Verdão SF 177 ' $\left(C_{1}\right)$ and $9.26 \%$ for the cultivar 'Português Pacífico' $\left(C_{2}\right)$, per unit increase in irrigation water salinity (Figure $1 \mathrm{~A}$ ). It can also be observed that the reductions in EP were more pronounced in $\mathrm{C}_{1}$ than in $\mathrm{C}_{2}$, which indicates greater sensitivity to salinity in $\mathrm{C}_{1}$ in the germination stage, when compared with the cultivar $\mathrm{C}_{2}$.

The progressive increase in irrigation water salinity linearly reduced the growth in $\mathrm{PH}, \mathrm{SD}$ and $\mathrm{NL}$ of the coriander cultivars (Figure 1B, C and D). The cultivar $\mathrm{C}_{2}$ showed the highest reductions in the growth in $\mathrm{PH}$ and $S D$, in relation to $C_{1}$, per unit increase in irrigation water salinity. However, the cultivar $\mathrm{C}_{2}$ obtained the greatest growth in PH, SD and NL at all studied levels of salinity, in comparison with $\mathrm{C}_{1}$, showing greater growth potential, even under saline stress conditions, thus expressing higher tolerance to salinity.

The reductions in $\mathrm{EP}, \mathrm{PH}, \mathrm{SD}$ and $\mathrm{NL}$ are related to the decrease in the osmotic potential of the substrate, due to the accumulation of salts, increasing soil salinity and sodicity and, therefore, inhibiting the imbibition of seeds, germination and, consequently, seedlings emergence and the initial growth of coriander plants. The observed results corroborate those of Sales et al. (2015), Oliveira et al. (2015a) and Albuquerque et al. (2016), who evaluated emergence and initial growth of seedlings of coriander, beet and cucumber, respectively, under different levels of irrigation water salinity. These authors pointed out that the excessive increase in the salinity of the substrate, due to the saline irrigation water, directly affects the physiological responses of the seeds, besides causing hormonal disorders in young plants; thus, leading to reductions in emergence and initial growth of the plants.

As observed for emergence and initial growth, phytomass accumulation was also reduced as a function of the increase in irrigation water salinity, with reductions of 2.31, 0.38 and $2.69 \mathrm{mg}$ for SDM, RDM and TDM, respectively, in plants of the cultivar $\mathrm{C}_{1}$, and reductions of 2.23, 0.51 and $3.06 \mathrm{mg}$ for SDM, RDM and TDM, respectively, in plants of the cultivar $C_{2}$, per unit increase in irrigation water salinity (Figures $1 \mathrm{E}, \mathrm{F}$ and $\mathrm{G}$ ). Despite the higher reductions observed in $\mathrm{C}_{2}$, its phytomass accumulation at the highest salinity level $\left(3.0 \mathrm{dS} \mathrm{m}^{-1}\right)$ was 53.0, 32.1 and $45.6 \%$ higher for SDM, RDM and TDM, respectively, in comparison with those of $\mathrm{C}_{1}$ under the same salinity condition. Thus, the higher reductions observed in $\mathrm{C}_{2}$ are not related to its lower tolerance, but to its greater phytomass accumulation in relation to $C_{1}$.

The reduction in phytomass accumulation is related to the deleterious effects caused by the saline stress, since the high concentrations of sodium salts interact negatively with the physiological aspects of the plant, promoting ionic, osmotic, hormonal and nutritional alterations that are deleterious to the plants, causing reductions in growth and, consequently, in phytomass accumulation (Flowers and Flowers, 2005; Munns and Tester, 2008; Esteves and Suzuki, 2008; Taiz and Zeiger, 2013). The reduction in phytomass accumulation as a function of the increase in irrigation water salinity was also observed in the coriander crop by Oliveira et al. (2010) and Rebouças et al. (2013), as well as in other vegetables: lettuce (Oliveira et al., 2011); broccoli (Maciel et al., 2012); pumpkin (Oliveira et al., 2014); cabbage (Oliveira et al., 2015b); melon (Araújo et al., 2016), cucumber (Albuquerque et al., 2016) and eggplant (Oliveira et al., 2016).

The results observed in the salinity tolerance index confirm the results observed for emergence, growth and phytomass accumulation, with linear reductions in the tolerance as irrigation water salinity increased (Figure $1 \mathrm{H})$. Considering the classification of Fageria et al. (2010), based on four levels: T (tolerant; 0 to 20\%), MT (moderately tolerant; 21 to $40 \%$ ), MS (moderately sensitive; 41 to $60 \%$ ) and S (Sensitive; $>60 \%$ ), adopting the total dry matter of plants not subjected to salinity as the reference, the cultivar 'Verdão SF 177' $\left(C_{1}\right)$ was moderately sensitive to salinity from the level of $1.94 \mathrm{dS}$ $\mathrm{m}^{-1}$, while 'Português Pacífico' $\left(C_{2}\right)$ was moderately sensitive to salinity from the level of $2.70 \mathrm{dS} \mathrm{m}^{-1}$, in the initial growth stage. 
A.

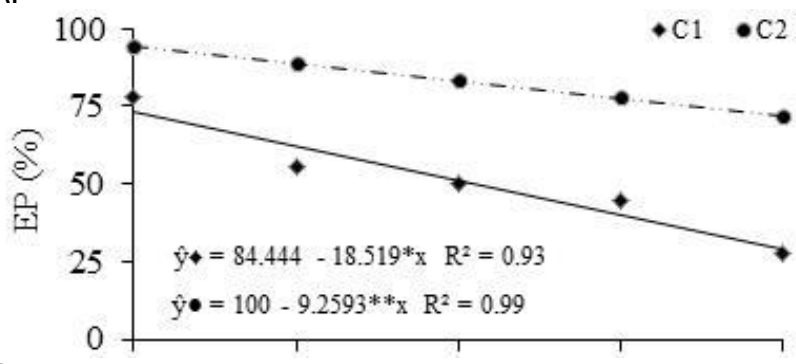

C.

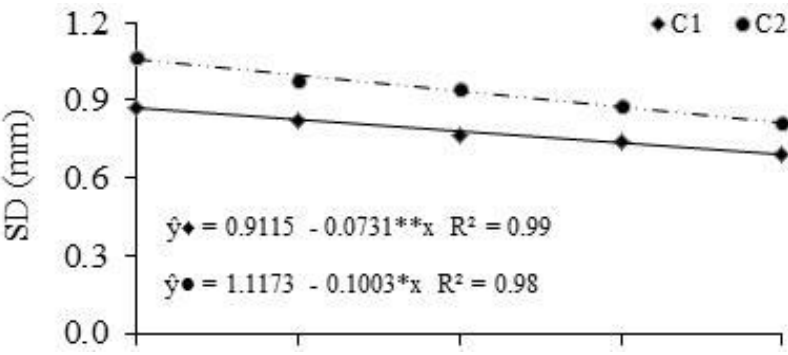

E.

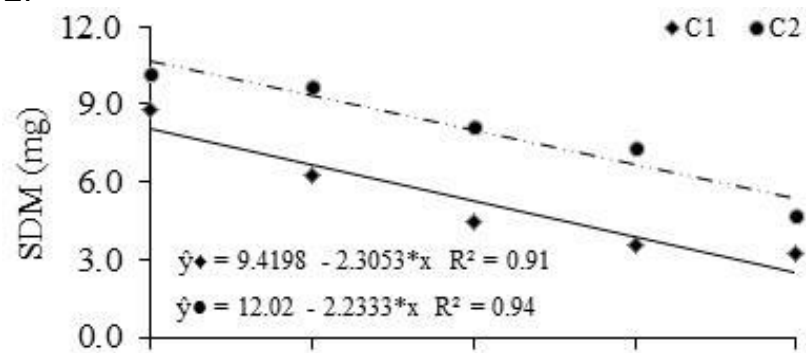

G.

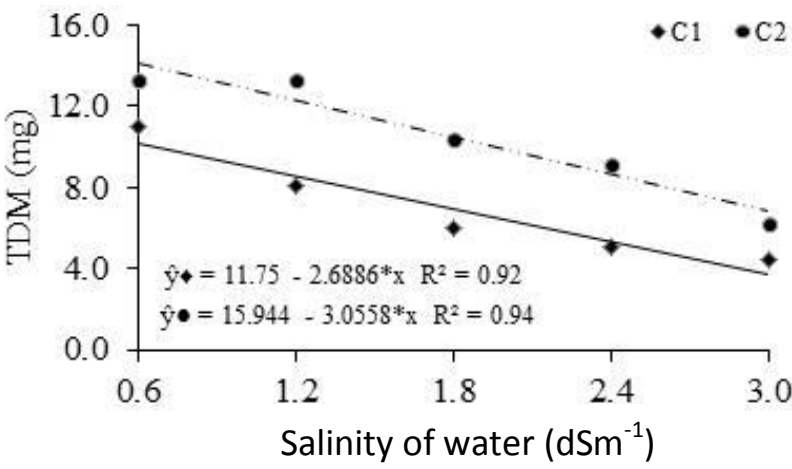

B.

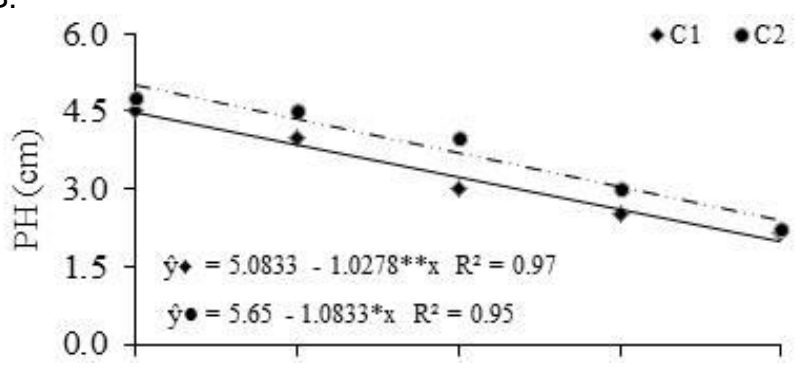

D.

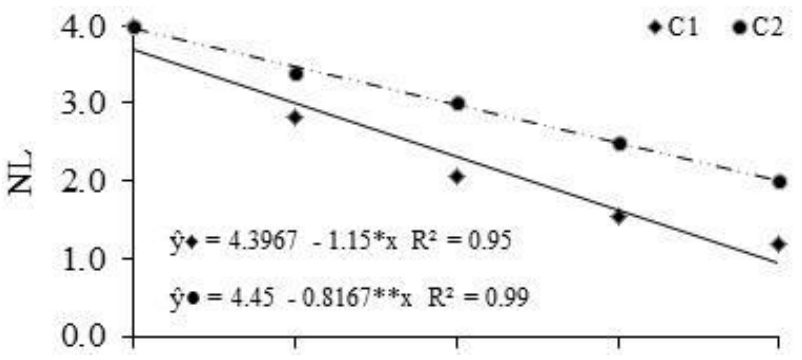

F.

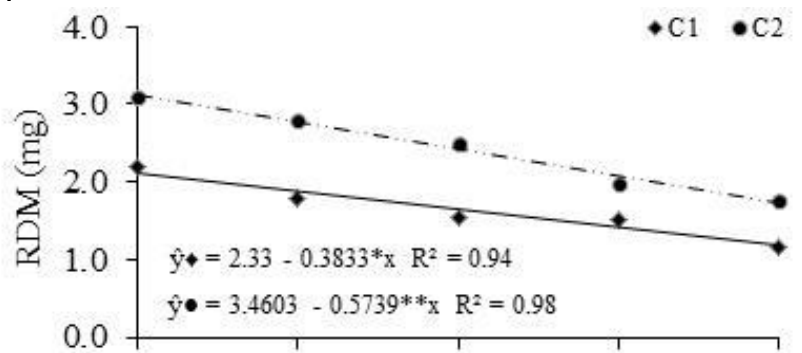

$\mathrm{H}$.

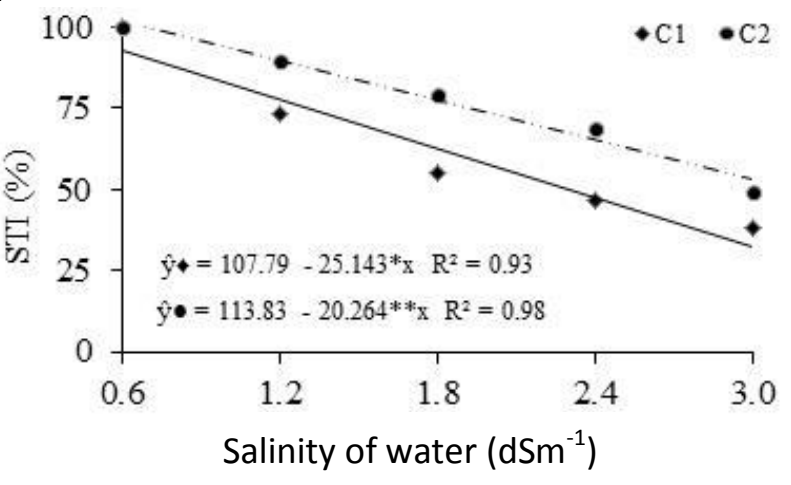

Figure 1. Emergence percentage (EP) (A.), plant height (PH) (B.), stem diameter (SD) (C.), number of leaves (NL) (D.), shoot dry matter (SDM) (E.), root dry matter (RDM) (F.), total dry matter (TDM) (G.) and salinity tolerance index (STI) (H.) of coriander cultivars ( $\mathrm{C}_{1}$ - 'Verdão SF 177' and $\mathrm{C}_{2}$ - 'Português Pacífico') under different levels of irrigation water salinity. ${ }^{* *}=$ Significant at 0.01 probability level; Equal letters do not differ by Tukey test at 0.05 probability level.

\section{Conclusions}

The increase in irrigation water salinity reduced emergence percentage, growth and phytomass accumulation of coriander plants. The cultivar 'Português Pacifico' is more tolerant to salinity when compared with the cultivar 'Verdão SF 177'. The cultivars 'Português Pacífico' and 'Verdão SF 177' can be irrigated with water of up to 2.6 and $1.9 \mathrm{dS} \mathrm{m}^{-1}$, respectively, in the initial growth stage.

\section{Conflict of Interests}

The authors have not declared any conflict of interests.

\section{REFERENCES}

Albuquerque JRT, Sá FVS, Oliveira FA, Paiva EP, Araújo EBG, Souto 
LS (2016). Crescimento inicial e tolerância de cultivares de pepino sob estresse salino. Rev. Bras. Agric. Irrigada, 10(2):486-495.

Araujo EBG, da Silva Sá FV, de Oliveira FA, Souto LS, de Paiva EP, do Nascimento SMK, de Mesquita EF, Brito MEB (2016). Crescimento inicial e tolerânçia de cultivares de meloeiro à salinidade da água. Rev. Ambiente Água, 11(2):462.

Ayers RS, Westcot DW (1999). A qualidade da água na agricultura. 2.ed. Campina Grande: UFPB, 1999. 153p. FAO. Estudos de Irrigação e Drenagem, 29 revisado.

Empresa Brasileira De Pesquisa Agropecuária (EMBRAPA) (2011). Centro Nacional de Pesquisa de Solos. Manual de métodos de análise do solo. 3. ed. Rio de Janeiro, 230 p. (Documentos, 132).

Empresa Brasileira De Pesquisa Agropecuária - EMBRAPA (2013). Centro Nacional de Pesquisa de Solos. Sistema Brasileiro de Classificação de Solos. 3. ed. Brasília, DF: Embrapa Solos,. 353p.

Esteves BS, Suzuki MS (2008). Efeito da salinidade sobre as plantas. Oecologia brasiliensis 12(3):662-679.

Fageria NK, Soares FWS, Gheyi HR (2010). Melhoramento genético vegetal e seleção de cultivares tolerantes à salinidade. In: Manejo da salinidade na agricultura: Básicos e aplicados. INCTSal, cap 13:205216.

Ferreira DF (2011). Sisvar: a computer statistical analysis system. Ciência e Agrotecnologia 35(6):1039-1042.

Flowers TJ, Flowers SA (2005). Why does salinity pose such a difficult problem for plant breeders? Agric. Water Manag., 78(1):15-24.

Maciel KS, Lopes JC, Mauri J (2012). Germinação de sementes e vigor de plântulas de brócolos submetida ao estresse salino com $\mathrm{NaCl}$. Nucleus, 9(2):221-228.

Medeiros JF, Silva MCC, Sarmento DHA, Barros AD (2007). Crescimento do meloeiro cultivado sob diferentes níveis de salinidade, com e sem cobertura do solo. Rev. Bras. Engenharia Agríc. Ambient., 11(3):248-255.

Munns R, Tester M (2008). Mechanism of salinity tolerance. Ann. Rev. Plant Biol. 59(3):651-681.

Oliveira FA, Carrilho MJSO, Medeiros JF, Maracajá PB, Oliveira MKT (2011). Desempenho de cultivares de alface submetidas a diferentes níveis de salinidade da água de irrigação. Rev. Bras. Engenharia Agríc. Ambient., 15(8):771-777.

Oliveira FA, Martins DC, Oliveira MKT, Souza Neta ML, Ribeiro MSS, Silva RT (2014). Desenvolvimento inicial de cultivares de abóboras e morangas submetidas ao estresse salino. Agro@mbiente On-line, $8(2): 222-229$.
Oliveira FA, Sá FVS, Paiva EP, Araújo EBG, Silva MKN, Andrade RA, Moreira RCL, Solto LS (2015b). Emergência e crescimento inicial de plântulas de repolho cv. Chato de Quintal sob estresse salino. Agropecu. Técnica 36(1):273-279.

Oliveira FS, Sá FVS, Souto LS, Paiva EP, Oliveira FA, Araújo EBG, Oliveira NHT (2016). Seedling of development and tolerance of eggplant cultivars under saline stress. Afr. J. Agric. Res. 11(26):23102315.

Oliveira KP, Freitas RMO, Nogueira NW, Praxedes SC, Oliveira FN (2010). Efeito da irrigação com água salina na emergência e crescimento inicial de plântulas de coentro cv. Verdão. Rev. Verde de Agroecologia e Desenvolvimento Sustentável 5(2):201-208.

Rebouças JRL, Ferreira NM, Dias NS, Souza NON, Diniz AA, Lira RB (2013). Cultivo hidropônico de coentro com uso de rejeito salino. Irrigation 18(4):624-634.

Rhoades JD, Kandiah A, Mashali QM (1992). The use of saline waters for crop production. Rome: FAO. (Irriga. Drainage Paper, 48). 133p.

Sales MAL, Moreira FJC, Eloi WM, Ribeiro AA, Sales FAL, Monteiro RNF (2015). Germinação e crescimento inicial do coentro em substrato irrigado com água salina. Braz. J. Biosyst. Eng. 9(3):221227.

Santana MJ, Carvalho JA, Souza KJ, Sousa AMG, Vasconcelos CL, Andrade LAB (2007). Efeitos da salinidade da água de irrigação na brotação e desenvolvimento inicial da cana-de-açúcar (Saccharum spp) e em solos com diferentes níveis texturais. Ciênc. Agrotecnol. 31(5):1470-1476.

Silva MAD, Coelho Júnior LF, Santos AP (2012). Vigor de sementes de coentro (Coriandrum sativum L.) provenientes de sistemas orgânico e convencional. Rev. Bras. Plantas Med. 14:192-196.

Silva MG, Soares TM, Oliveira IS, Santos JCS, Pinho JS, Freitas FTO (2015). Produção de coentro em hidroponia nft com o uso de águas salobras para reposição do consumo evapotranspirado. Rev. Bras. Agric. Irrig. 9(4):246-258.

Taiz L, Zeiger E (2013). Fisiologia vegetal. Porto Alegre: Artmed, 5.ed. $918 p$. 